\title{
Protrusions Within a Pink-Yellow Plaque
}

\author{
Csongor Németh ${ }^{1}$, Melánia Pozsgai ${ }^{1}$, Rolland Gyulai ${ }^{1}$, Zsuzsanna Lengyel $^{1}$
}

1 Department of Dermatology, Venerology and Oncodermatology, Medical School, Clinical Center - University of Pécs, Pécs, Hungary

Citation: Németh C, Pozsgai M, Gyulai R, Lengyel Z. Protrusions within a pink-yellow plaque. Dermatol Pract Concept. 2022;12(1):e2022012. DOI: https://doi.org/10.5826/dpc.1201a12

Accepted: April 29, 2021; Published: January 2022

Copyright: $\odot 2022$ Németh et al. This is an open-access article distributed under the terms of the Creative Commons AttributionNonCommercial License (BY-NC-4.0), https://creativecommons.org/licenses/by-nc/4.0/, which permits unrestricted noncommercial use, distribution, and reproduction in any medium, provided the original authors and source are credited.

Funding: None.

Competing interests: None.

Authorship: All authors have contributed significantly to this publication.

Corresponding author: Zsuzsanna Lengyel MD, PhD. Department of Dermatology, Venerology and Oncodermatology, Medical School, Clinical Center - University of Pécs, Hungary. E-mail: lengyel.zsuzsanna@pte.hu

\section{Case Presentation}

A 74-year-old woman with a history of several skin tumors was referred to our center. She complained of a lesion localized on the right flank, growing for 15 months. Upon examination, a $75 \mathrm{~mm} \times 30 \mathrm{~mm}$ pinkish-yellowish plaque was observed. Within the lesion, three red, firm, keratotic papules were seen (Figure 1A). Dermoscopy showed yellow globules with indistinct borders on a whitish-erythematous background. In the yellowish structures, polymorphous vessels consisting of linear irregular vessels and curved vessels were seen. Within the papules hairpin, coiled vessels were present (Figure 1, B-D).

Due to the large size, an incisional biopsy was performed. Histopathology revealed the collision of an in-situ squamous cell carcinoma and superficial sebaceous carcinoma (SC). The lesion was excised with safety margin. Pathology confirmed the previous diagnosis.

\section{Teaching point}

Sebaceous carcinoma tends to mimic squamous and basal cell carcinomas. The presence of yellowish structures and polymorphous vessels are features suggestive of SC. Some suggest that extraocular SC might originate from preexisting intraepidermal squamous neoplasia [1,2].

Informed consent: Written informed consent for publication of clinical details and clinical images was obtained from the patient. 


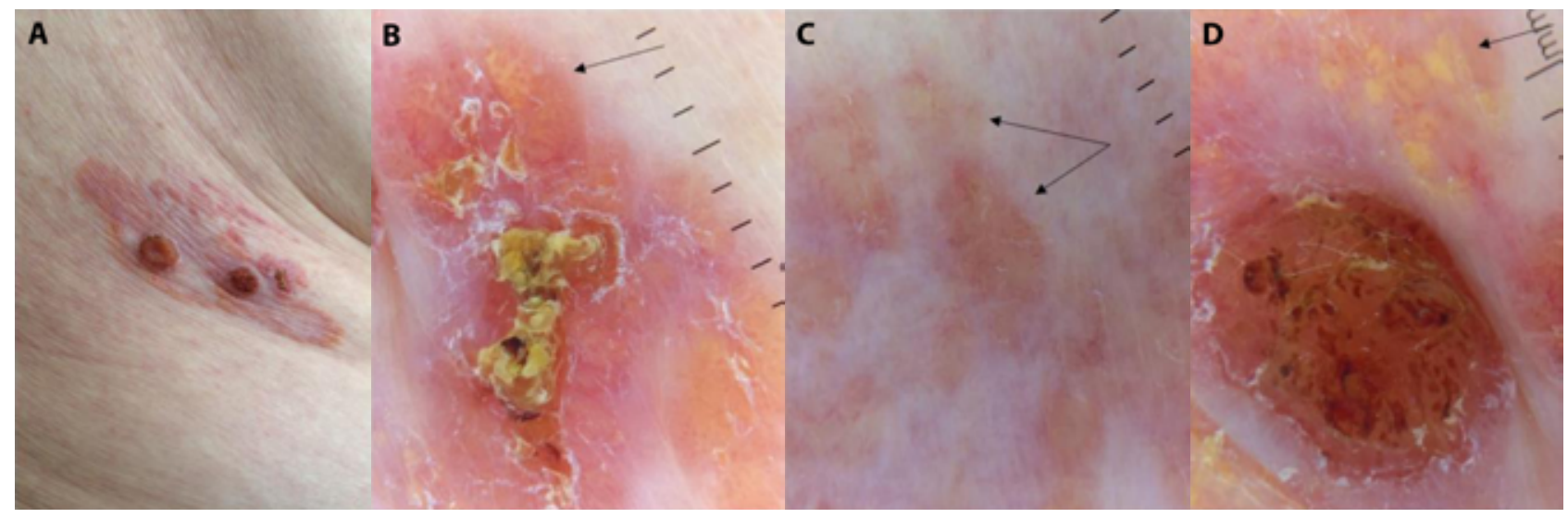

Figure 1. (A) Clinical picture of the lesion. (B-D) Dermoscopy demonstrated white-pink areas with yellow structures throughout the lesion with polymorphous vessels (arrows)

\section{References}

1. Horimoto K, Kato J, Sumikawa Y, et al. Dermoscopic features distinctive for extraocular sebaceous carcinoma. J Dermatol. 2018;45(4):487-490. DOI: 10.1111/1346-8138.14170. PMID: 29235655
2. Kogame T, Ohe S, Yamazaki F, Okamoto H, Kiyohara T. Extraocular sebaceous carcinoma accompanied by invasive squamous cell carcinoma: The first case report and consideration of histogenesis. J Dermatol. 2018;45(4):501-504. DOI: 10.1111/1346 -8138.14196. PMID: 29266386. 